\title{
Lepidopterous stem borers of maize (Zea mays): agro- ecological and regional composition and distribution of their parasitoids in Southern Ghana
}

\author{
Wisdom Harrison K. HORDZI \\ Department of Biology Education, Faculty of Science Education, University of Education, P. O. Box 25, Winneba, \\ Ghana. Email: wisdomhordzi@gmail.com, wisdomhordzi2@yahoo.com. \\ Copyright (@) 2018 Hordzi. This article remains permanently open access under the terms of the Creative Commons Attribution License 4.0, which \\ permits unrestricted use, distribution, and reproduction in any medium, provided the original work is properly cited.
}

Received 23rd January, 2018; Accepted 23rd February, 2018

\begin{abstract}
The study aimed at finding out the level of infestation of maize stem borers, their agro-ecological and regional composition and distribution of their parasitoids. Farms were made at University of Cape Coast in the major and minor cropping seasons and maize sown. Plant infestation was recorded weekly. Stem borer larvae and pupae collected from plants were reared until either parasitoids developed from them or they developed into pupae or adults. Rate of parasitization of each stem borer was calculated. In two national maize field surveys, field infestation by pests and parasitism were determined. Parasitoids that emerged from stem borer larvae and pupae were identified to species level. Diversity and distribution of parasitoids according to agro-ecological zones and national administrative regions were determined. Higher stem borer infestation was recorded in the minor season experimental plants. Also, higher number of stem borers was collected from plants during the minor season. Eldana saccharina was the most parasitized stem borer in the experimental farms. Surveys showed more parasitization of stem borers in the minor season. Ashanti and Western regions recorded the highest diversity of parasitoids and Eastern Region recorded the most abundant parasitoids. From both experimental farm and survey results Syzeuctus sp. was the most important parasitoid species of maize stem borers. These results provide useful information on the biology and activities of parasitoids that can be exploited for managing maize stem borers.
\end{abstract}

Key words: Agro-ecology, Busseola fusca, lepidopterous, management, parasitoid, Syzeuctus.

\section{INTRODUCTION}

Maize (Zea mays) serves as the source of food for people worldwide. It is the principal staple crop produced and consumed by most farming households in Ghana. This crop is well adapted and grows in most of the ecological zones of Ghana including the Northern Savannah (Adu, et al., 2014) where maize growing seasons and sowing dates vary according to the agro-ecological zones.

Despite the numerous use of maize, the crop is affected by many pests including insect pests that cause low levels of yield. According to Ntambo et al. (2015), in Africa, lepidopterous stem borers are generally considered to be the most damaging insect pests of maize and sorghum. Kfir et al. (2002) observed that Busseola fusca is considered to be the most destructive lepidopteran pests of maize in Africa. Estimates of crop losses vary greatly in different regions and agro-ecological zones. Yield losses of about $40 \%$ were reported in monocropped maize fields (Chabi-Olaye et al., 2005; Chabi-Olaye et al., 2008).

Currently, B. fusca presents a major constraint to the production of maize in areas where they are abundant (Paul-André et al., 2014). B. fusca larvae damage all plant parts of the cultivated crops they attack (Paul-André et al., 2014). In West Africa, it is of minor importance in the southern humid zones, but it is the dominant species on cultivated sorghum in the northern dry savannah zones (Harris and Nwanze, 1992).

The first instar larvae of most stem borer species initially feed on young leaf tissues, while older larvae tunnel into 
the stem tissues and feed internally (Bosque-Pérez and Schulthess, 1998). However, after hatching, Sesamia calamistis bores directly into the stem (Bosque-Pérez and Schulthess, 1998) and cause considerable damage leading to yield and financial losses. The larval stage can last for 25 to 58 days and may have 6 to 8 instars where pupation takes 5 to 14 days after which adult moths emerge (Harris 1990; Maes 1998). Maize stem borers pupate close to the tunnel exit or even partly outside the stem (Smith et al. 1993) and this increases their accessibility to parasitoids (Ndemah et al. 2001).

In Ghana, the major insect pests of cultivated maize in the field are the lepidopterous stem borers in the family Noctuidae (Agrotidae) which include Sesamia (nonagrioides) botanephaga Tams and Bowden, $S$. penniseti Tams and Bowden, S. calamistis Hampson, Busseola fusca and the Pyralidae comprising Eldana saccharina, Chilo spp. and Coniesta ignefusalis Hampson (Maafo, 1975; Kumar and Sampson, 1982).

Considering the destructive nature of the lepidopterous stem borers on maize in Ghana in particular and Africa as a whole, it is clear that these pests have become nuisance to maize production. In some agro-ecological zones of the country it is common to see maize stems conspicuously damaged by the stem borers and as a result the plants die. This gives farmers much problem because they do not attain the anticipated yield from their maize fields due to the damage caused by the stem borer pests.

Though a number of researches have been undertaken on these pests in maize fields in Ghana (Maafo, 1975; Kumar and Sampson, 1982) much needs to be done to understand the level of infestation, borer prevalence and parasitization, especially in relation to regional agroecological distribution and abundance of the parasitoid species. Therefore, this study was to determine the infestation of Lepidopterous maize stem borer pests, as well as their agro-ecological and regional composition and distribution of their parasitoids in southern Ghana.

The study was guided by the following research questions:

1. What is the extent of infestation by stem borers in relation to the age of the maize plants in the experimental farms?

2. What is the rate of parasitism of larval stem borers at each age of the maize plants in experimental farms?

3. What are the parasitoid species and their host range in experimental farms?

4. What is the ecological and regional composition and distribution of lepidopterous stem borers in Southern Ghana?

\section{MATERIALS AND METHODS}

\section{The study area}

Ghana is made up of 10 administrative regions (Figure 1).
There are six agro-ecological zones defined on the basis of climate, reflected by the natural vegetation and influenced by the soils (AQUASTAT, 2005). The common agro-ecological zones in Ghana are rain forest with rainfall of 2,200 mm/year; deciduous forest with $1,500 \mathrm{~mm} /$ year rainfall; transition zone with $1,300 \mathrm{~mm} /$ year rainfall; Guinea Savannah having $1,100 \mathrm{~mm} /$ year rainfall; Sudan Savannah which has rainfall of $1,000 \mathrm{~mm} /$ year and Coastal savannah with $800 \mathrm{~mm} /$ year rainfall (AQUASTAT, 2005; Ministry of Food and Agriculture (MOFA), 2011). Rainfall distribution is bimodal in the forest, transitional and coastal zones, giving rise to major and minor growing seasons. In the remaining two agro-ecological zones, the unimodal rainfall distribution gives rise to only one growing season (AQUASTAT, 2005).

\section{Experimental farms}

Two farms were established, one in the University of Cape Coast farm and the other in the University Cafeteria. Cape Coast is along the Coastal savannah zone. The land was prepared by ploughing and harrowing. It was purely under rain-fed condition. A preliminary experimental farm was established from November 1995 to February, 1996. Two other experimental farms, one for the major (first) season (May to July) and the other for the minor (second) season (August to December) were established in 1996, in the University of Cape Coast farm. Another farm was established about 50 metres to the University Cafeteria from August to December.

The dimension of each of the farms was $30 \mathrm{~m}$ by $29 \mathrm{~m}$. All plantings were done at a spacing of one metre between rows and 0.30 metres between hills within rows. Three seeds per hole were initially planted and thinned to two plants per hill after germination. The maize variety known as "Obatanpa" with maturity period of 105 to 120 days (Crop Research Institute (CRI), 1996) was obtained from commercial seed growers and sown. Weed control was done by hoeing. There was no weedicide or insecticide application.

Sampling for field infestation started three to four weeks after emergence of seedlings and continued until maturity of the maize. At pre-tasselling stages (stage $1=3$ to 5 seed leaves; stage $2=6$ to 8 seed leaves; stage $3=9$ to 11 seed leaves and stage $4=$ mid whorl or 12 leaves and above), the plants were sampled randomly for stem borer eggs, larvae, pupae and frass. This was done by choosing five one metre quadrats in the field. Plants that fell within each quadrat were examined for the presence or absence of stem borer eggs, larvae, pupae and frass (evidence of infestation).

Sampling for the percentage plant infestation was done weekly. For each week, 40 plants were examined randomly from the five quadrats to find out the level of plant infestation by stem borers in the field. Plants that had borer 


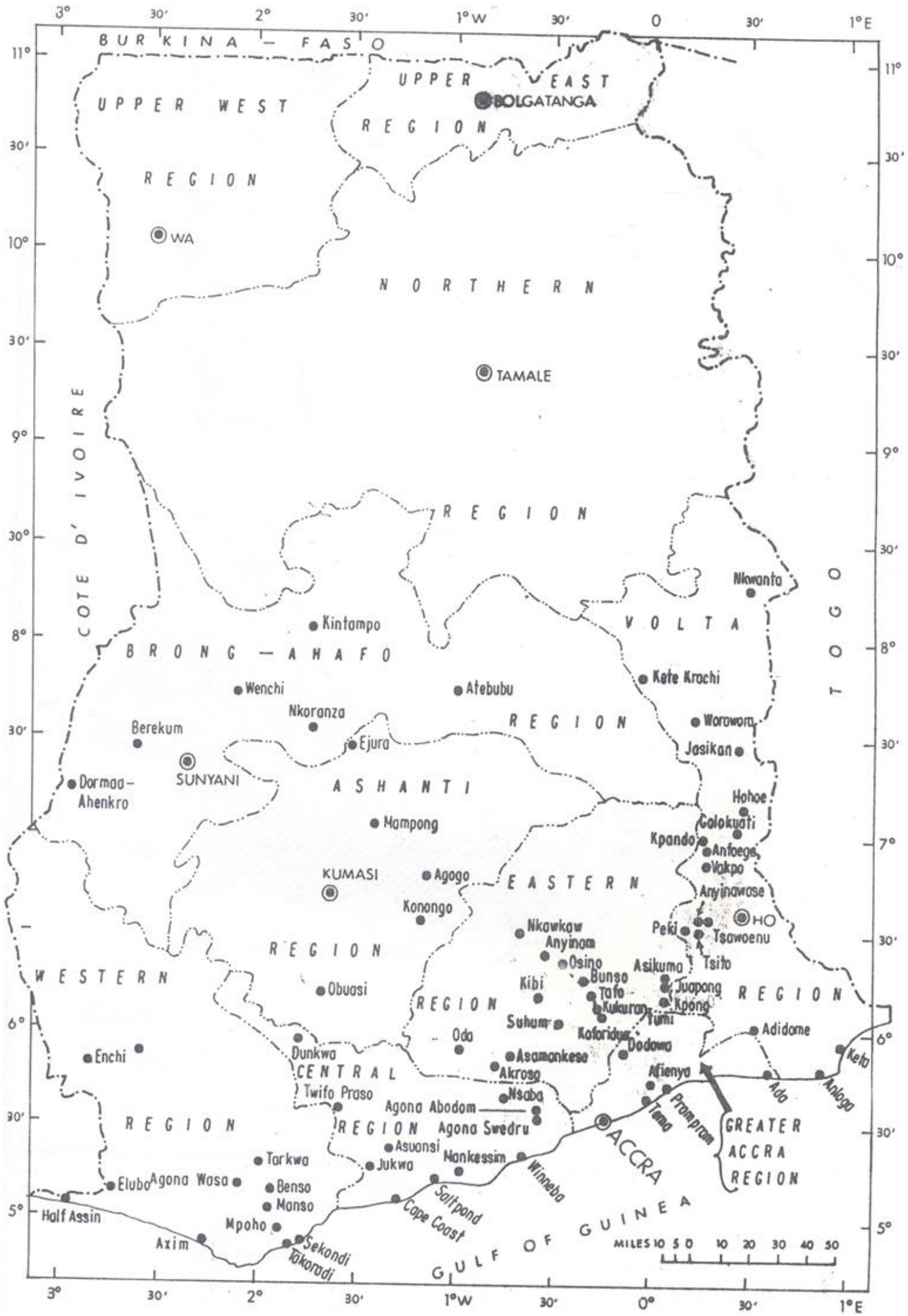

Figure 1. map of Ghana showing the administrative regions. 


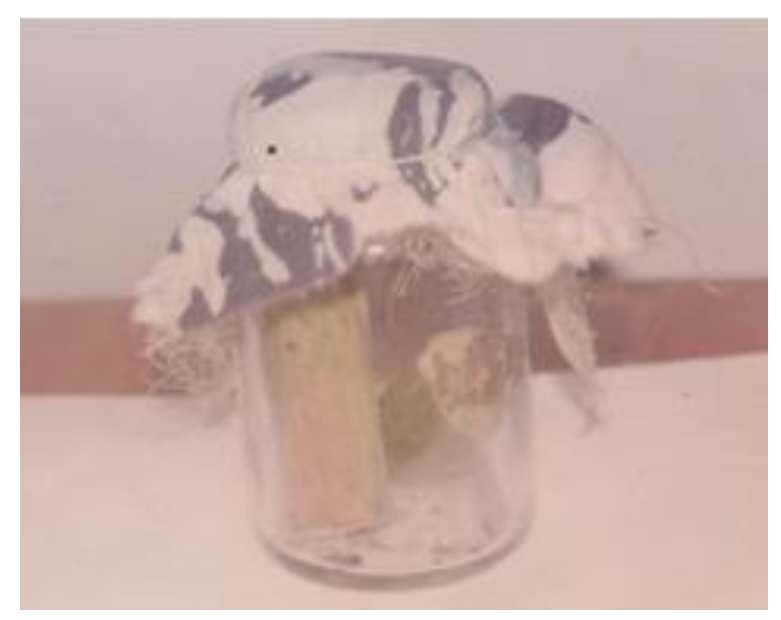

Plate 1. Bottle depicting how the larvae were fed $\left(X^{1} / 4\right)$.

eggs, frass, borer holes, dead hearts and borer larvae or pupae were recorded as infested. On each sampling day all infested plants were uprooted. At most 15 plants out of the total infested ones were randomly selected and dissected for stem borer larvae and pupae. The percentage field infestation for each week was calculated using the following formula: total number of infested plants divided by $40 \times 100$. Figures obtained were used to plot graphs for each field covering the sampling time. New quadrates were chosen for the next sampling day.

All eggs collected were counted and each egg batch was kept in a petri-dish in the laboratory at room temperature. Daily observations were made for emergence of stem borer larvae or parasitoids. The stem borer larvae and pupae collected from the plants were identified and separated into the various species (Sesamia spp., Eldana sacchirina, Busseola fusca, Chilo aleniellus). Each larva was put into $200 \mathrm{~cm}^{3}$ bottle. The pupae were also put into separate bottles and covered with fine-mesh net or cloth (Plate 1) for good aeration. The larvae were fed on maize stem pieces until parasitoids emerged or end of the development cycle of the insect pest. The parasitoids that emerged from each stem borer species were identified in the laboratory using keys provided by Polaszek (1994) and Polaszek and Lassale (1995). All dead larvae that did not produce any parasitoids were dissected to find out the presence of parasitoids and those found containing parasitoid pupal cases were considered parasitized. Number of larvae that produced parasitoids was recorded. The rate of parasitization for each stem borer species was weekly calculated using the formula: total number of borers from which parasitoids were collected divided by number of the borer species $\times 100$. The calculated figures were presented in tables for interpretation.

\section{Surveys}

Two surveys, one in the major season and the other in the minor season were carried out, each in 6 administrative regions of Ghana when the maize plants were at the tasselling and after-tasselling stages. Thus, (stage $5=$ tassel or silking stage; stage $6=\mathrm{cob}$ or beans formation or milking stage; stage 7 = end of milking or soft dough stage; stage $8=$ hard dough stage; stage $9=$ matured maize stage; stage $10=$ harvesting stage) using roadside fields approximately 20 to $30 \mathrm{~km}$ apart. Forty-six fields were sampled for the major season whilst 40 fields were sampled during the minor season survey. Attempts were made to sample the same fields in regions that were visited the second time during the minor season survey, but other fields were sampled when necessary. Field infestation by pests and parasitism were done as in the experimental farms.

Parasitoids that emerged from dead larvae and pupae for the different stem borer species were kept separately and containers were labeled to show the location from which they were collected. Each parasitoid was then identified in the laboratory up to the species level with reference to keys provided by Polaszek (1994) and Polaszek and Lassale (1995). The composition and distribution according to ecological zones and national administrative regions were determined.

\section{Data analysis}

Descriptive statistics mainly frequencies and percentage frequencies were used.

\section{RESULTS AND DISCUSSION}

In this study, the main stem borer species found infesting the maize plants in the experimental farms were Sesamia spp., E. saccharina, B. fusca and C. aleniellus (Strand) (Plate 2). These findings are similar to that of Kumar and Sampson (1982) who reported that the major insect pests of cultivated maize in the field in Ghana were lepidopterous stem borers, E.saccharina, Chilo spp. and Coniesta ignefusalis, S. calamistis, S. botanephaga, S.pennisetiand $B$. fusca. Kwapong (1990) also made similar observations when he reported $C$. aleniellus attacking cultivated maize in the Central region of Ghana. Ntambo et al. (2015) also reported that out of the various insect pests attacking cereal crops in Africa, lepidopteran stem borers, $B$. fusca and $C$. partellus were by far the most injurious causing maize yield losses in many countries.

The average percentage plant infestation for the preliminary studies was $18.13 \%$ (Figure 2) while that of the major season was $15.29 \%$ (Figure 3 ). In the two cases the highest percentage plant infestation was recorded when the plants were 11 weeks old ( 30 and $43 \%$ respectively). Higher rates of infestation were recorded for the minor season studies. Averages of $51.5 \%$ (20 to $84.5 \%$ ) and 


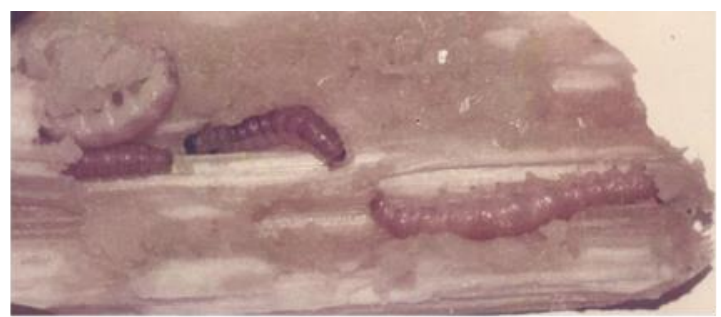

A

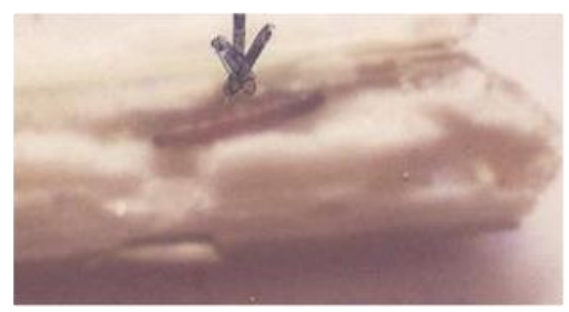

C

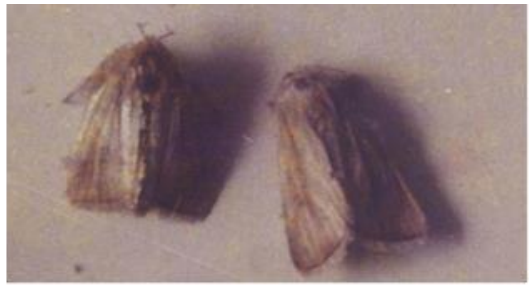

B

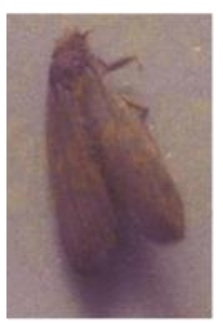

D

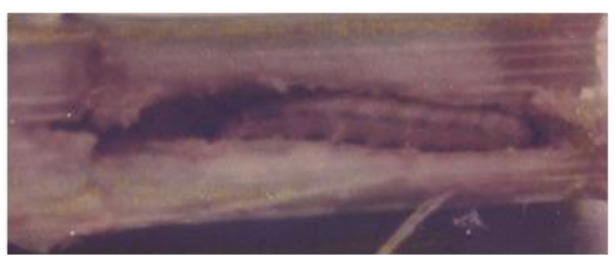

$\mathrm{E}$

Plate 2. Some stem borers collected from the experimental farms: (A) Larvae of Sesamia spp. in maize stem piece (X4); (B) Adult Sesamia moths (X4); (C) Larval E. saccharina in maize stem piece (arrowed) (X5); (D) Adult E. saccharina moth X4; (E) Busseola fusca larva in maize stem piece $(\mathrm{X} 3)$.

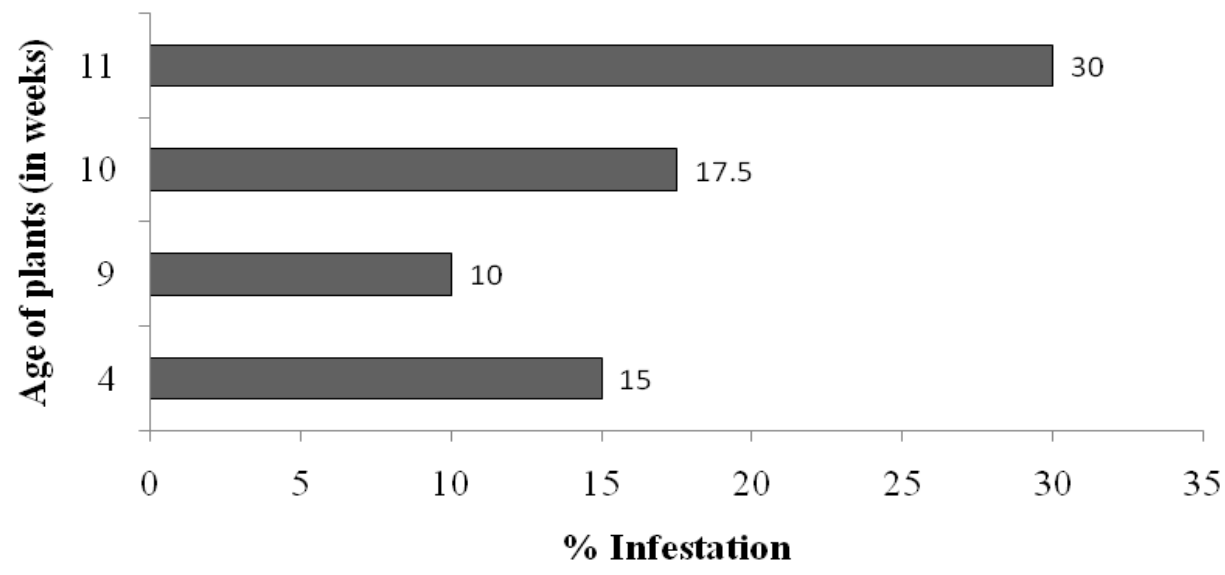

Figure 2. Percentage infestation by stem borers in relation to age of plants during preliminary study in the University farm.

$61.63 \%$ (18 to $86 \%$ ) were recorded for work in the University Cafeteria and the farm respectively (Figures 4 and 5). The highest (84.5\%) infestation was recorded when the plants were six weeks old at the University 


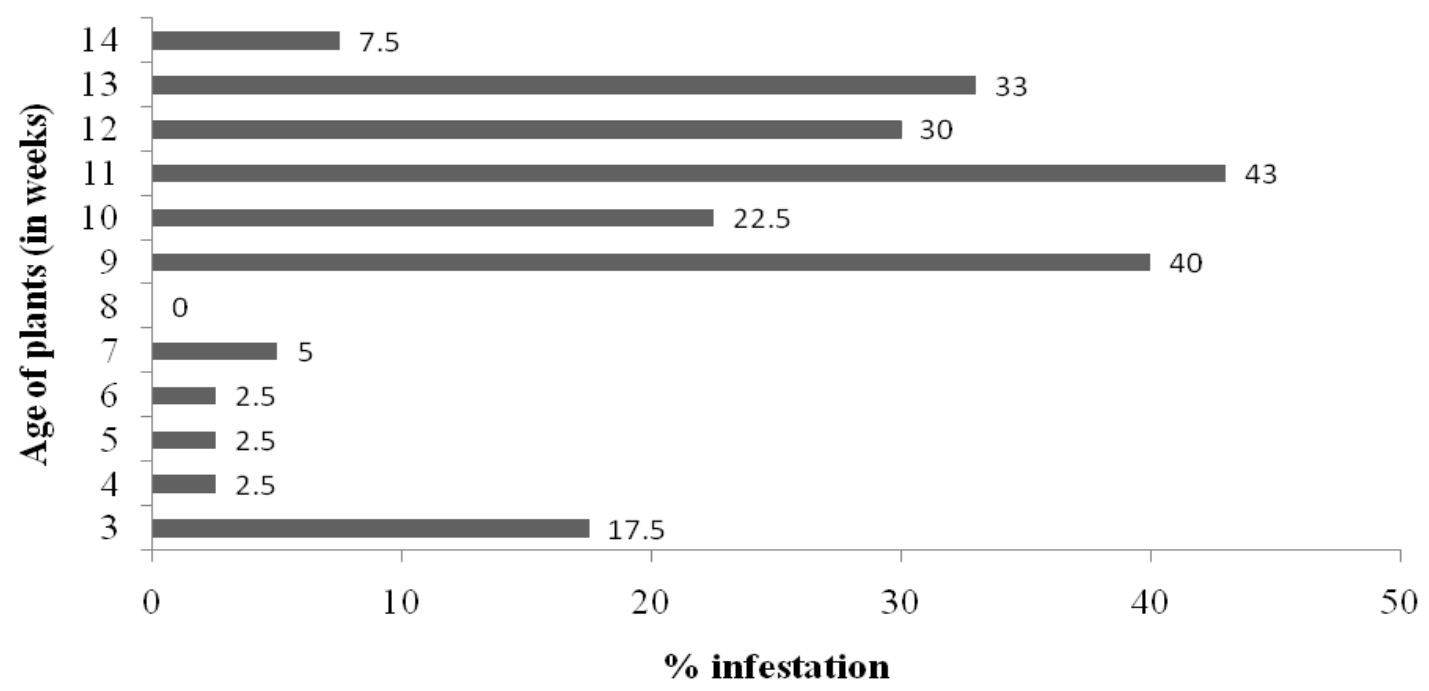

Figure 3. Percentage infestation by stem borers in relation to age of the plants during major season study in the University farm.

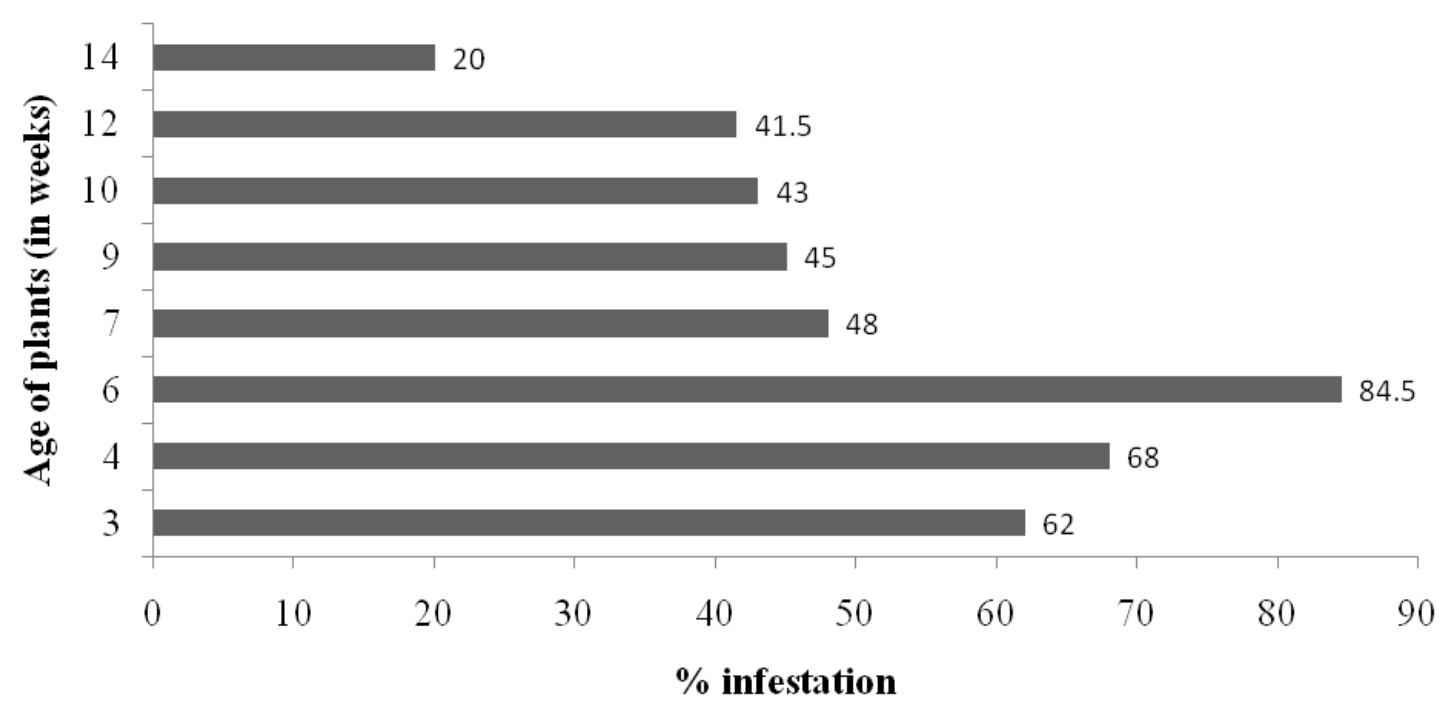

Figure 4. Percentage infestation by stem borers in relation to age of plants during the minor season study at the University Cafeteria.

Cafetaria (Figure 4), while in the University farm the highest infestation (86\%) was recorded when the plants were ten weeks old (Figure 5).

The study revealed that Sesamia spp. infestation of the maize plants began as early as three weeks when the seedlings were about $28 \mathrm{~cm}$ tall and remained till harvest. Similarly, $B$. fusca infested the plants about the same time as Sesamia. Shanower et al. (1991) and Kaufman (1983) reported that Sesamia spp. affect young maize when the maize seedlings are about $30 \mathrm{~cm}$ tall and increase until the pre-tasseling stage.
Infestation by $E$. saccharina occurs late in the development of the maize plant (Bosque-Perez and Mareck, 1991), especially from the seventh week of emergence of the crop. In this study, E. saccharina attack began when plants were 7 weeks old, 9 weeks old and 11 weeks old for minor season experiments, preliminary experiments and major season experiments respectively, which corroborates the reports of Bosque-Perez and Mareck (1991).

Ntambo et al. (2015) reported severe damage caused by the larvae of $B$. fusca and $C$. partellus that feed on the plant 


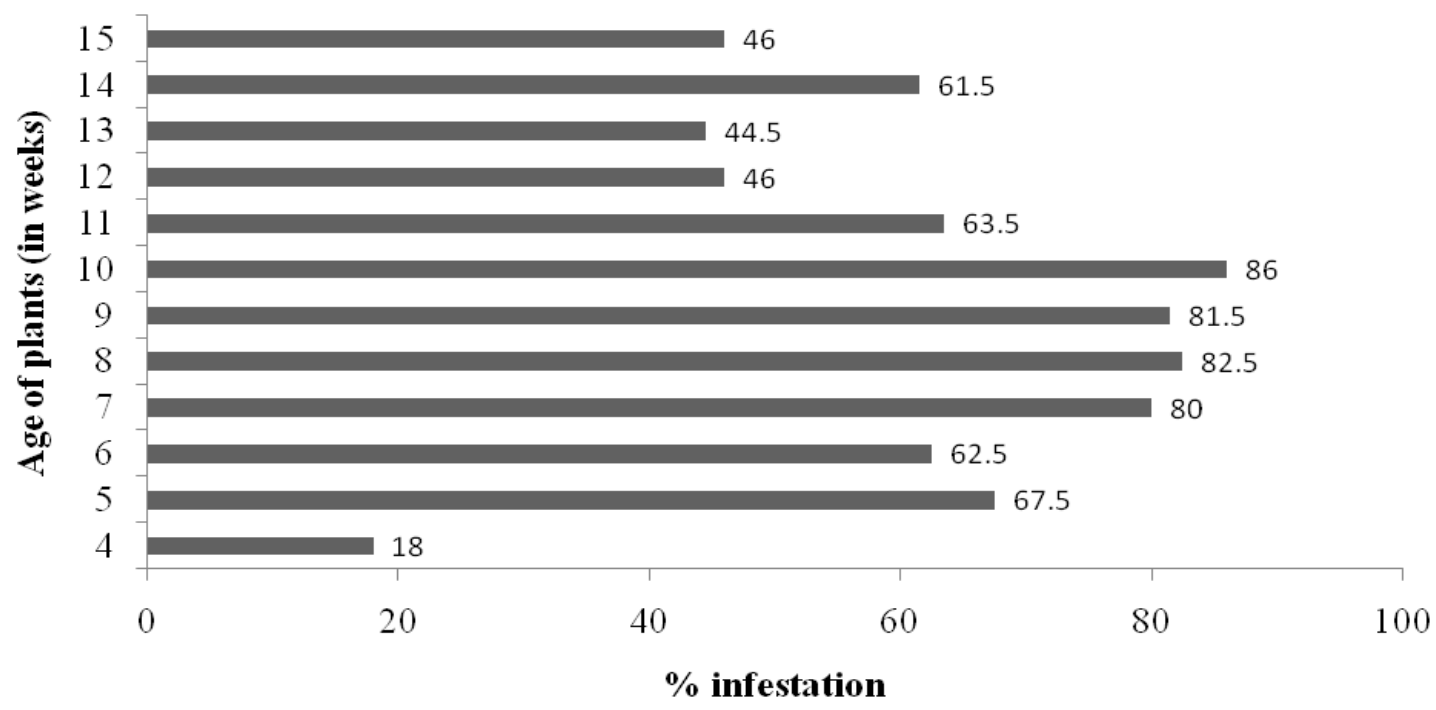

Figure 5. Percentage infestation by stem borers in relation to age of plants during the minor season study in the University farm.

from early stage up to maturity causing a devastating impact on maize yield. The results of this study however indicated that infestation by $C$. aleniellus began when the maize plants were between 7 and 9 weeks old. The cumulative effects of early as well as the late infesting pests, coupled with overlapping generations of the stem borers might have contributed to the high infestations when the plants were 6 to 11 weeks old.

However, from 12 weeks onwards, the maize plants were matured and drying had set in. The crop at that stage was less attractive to adult female stem borers for oviposition. Furthermore, the plants had become less suitable for larval feeding. The adult stem borers might have also left the maize plants for new ones elsewhere or enter into their wild hosts which resulted into the reduction in number of the stem borers infesting the maize plant from the 12th week, hence the low infestation after the 11th week.

Tounou et al. (2013) reported that percentage of infested plants ranged from 0 to $72 \%$ in the first cropping season, and 33 to $95 \%$ in the second cropping season showing higher infestation in the second cropping season. Similar results were obtained in this study where generally, there were higher infestations by stem borers during the minor season experiments than the preliminary and major season experiments. This might be due to the fact that; the second season crop was exposed to a population of borers that have built up considerably from the previous season as reported by Ingram (1958).

Though egg scouts were made throughout the experimental period in the experimental farms, it was only during two occasions in the minor season that ten egg batches were collected. This could be due to the possibility that eggs were laid at spots of the plant where they were difficult to locate as reported by Sampson and Kumar (1985). No egg parasitoids were found probably due to the scanty number of the eggs collected. This is at variance with the findings of Ntambo et al. (2015) who reported some parasitoids attacking eggs, larvae and pupae in their work. In the same study they observed Trichogramma spp. (Hymenoptera: Trichogrammatidae) and Platytelenomous busseola (Hymenoptera) as egg parasitoids that contribute to natural mortality of stem borers.

During the preliminary studies, a total of 105 larvae (Sesamia spp. $=47$ and E. saccharina $=58$ ) were collected while 108 larvae (Sesamia spp. $=55$; E. saccharina $=20$ and $C$. aleniellus $=33$ ) were collected during the major season experiment from the maize plants. However, in all, no parasitism was recorded; as such no parasitoid emerged from any of the stem borers.

Results of stem borer larval parasitism in the minor season at the University Cafeteria are presented in Table 1. The total number of larvae of stem borers collected from maize stems was 299 (Sesamia spp. = 203; E. sacchana $=40 ; B$. fusca $=49$ and $C$. aleniellus $=7$ ). For three week old plants, 2.70 and $20.00 \%$ parasitism were recorded on Sesamia spp. and B. fusca respectively. When the plants were ten and twelve weeks old, 22.22 and $10.00 \%$ of $E$. saccharina were parasitized respectively. C.aleniellus was not parasitized during the minor season experiment at the University Cafeteria. In the minor season at the Cafeteria, Syzeuctus sp. (Hymenoptera: Ichneumonidae) (Plate 3a) was reared from $E$. saccharina when the plants were ten and twelve weeks old (Table 1). An unidentified Chloropid (Plate $3 b$ ) was also reared from Sesamia sp. when the plants were three weeks old (Table 1). 
Table 1. Number of stem borer larvae and rate of parasitism at each age of the maize plants at the University Cafeteria in the minor season.

\begin{tabular}{ccccccccc}
\hline $\begin{array}{c}\text { Age of plant } \\
\text { (in weeks) }\end{array}$ & \multicolumn{2}{c}{ Sesamia spp. } & \multicolumn{2}{c}{ Eldana saccharina } & \multicolumn{2}{c}{ Busseola fusca } & \multicolumn{2}{c}{ Chiloaleniellus } \\
\cline { 2 - 8 } & No & $\%$ parasitism & No & \% parasitism & No & \% parasitism & No & $\%$ parasitism \\
\hline 3 & 37 & 2.70 & 0 & - & 10 & 20.0 & 0 & - \\
4 & 14 & 0.0 & 0 & - & 5 & 0.0 & 0 & - \\
6 & 69 & 0.0 & 0 & - & 0 & - & 0 & - \\
7 & 34 & 0.0 & 16 & 0.0 & 26 & 0.0 & 3 & 0.0 \\
9 & 29 & 0.0 & 0 & - & 1 & 0.0 & 0 & - \\
10 & 7 & 0.0 & 9 & 22.22 & 2 & 0.0 & 2 & 0.0 \\
12 & 11 & 0.0 & 10 & 10.0 & 4 & 0.0 & 1 & 0.0 \\
14 & 2 & 0.0 & 5 & 0.0 & 1 & 0.0 & 1 & 0.0 \\
Total & 203 & 2.70 & 40 & 32.22 & 49 & 20.0 & 7 & 0.0 \\
\hline
\end{tabular}

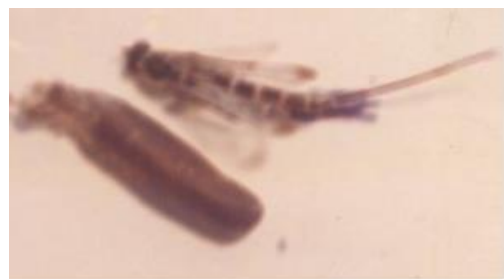

A

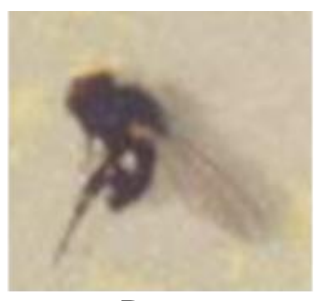

B

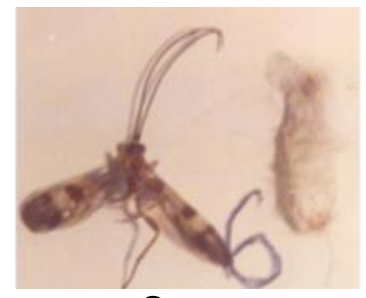

C

Plate 3. Parasitoids collected from borers/stem tunnels from experimental farms: (A) Syzeuctussp. and pupa case (X5); (B) Chloropid (X8); (C) Stenobracon sp. and pupa case (6 written for identification) $\mathrm{X} 6$.

Chloropids such as Epimadiza sp., Polyodaspis milii Seguy (as Oscinossoma milli) and polyodapsis risbeci Seguy (as Oscinossoma risbeci) were listed by Risbec (1960) as parasitoids of stem borers in West Africa. However, Deeming (1972) observed that, although some Chloropid larvae were phytophagous and were often reared from shoots that had been previously damaged by shoot flies of the genus Atherigona, in some cases might possibly be predaceous, especially on other dipterous larvae. In other cases, they were secondarily feeding as scavengers on decaying tissues (Deeming, 1972). There are no true records of true parasitism by Chloropids. In this study, the Chloropid specimen emerged from Sesamia larva. This suggests further that it could be a parasitoid.

A total of 387 larvae including 262 Sesamia spp; $75 E$. saccharina; 47 B. fusca and $3 C$. aleniellus were collected from maize stems during minor season experiment in the University farm (Table 2). Out of these 5.88 and $25 \%$ of $E$. saccharina were parasitized when the plants were thirteen and fifteen weeks old respectively. Stenobracon sp. (Hymenoptera: Braconidae (Plate $3 c$ and Table 3) was the parasitoid collected from the University farm in the minor season. Its pupa was collected from stem borer tunnel in the maize plant.

Tounou et al. (2013) reported that out of the total borer species recovered in their study the most abundant was S. calamistis $(76.02 \%)$, followed by B. fusca $(21.71 \%)$ and then E. saccharina $(2.27 \%)$. In this study also, the stem borer with the highest number of larvae collected from the plants in the experimental farms was S. calamistis (720), followed by E. saccharina (233), B. fusca (145) and C. aleniellus (50). These findings confirmed the reports of Tounou et al. (2013). Therefore, S. calamistis is the most important stem borer pest on maize from the experimental area. This does not mean that the other three species are not important, especially, E. saccharina and $B$. fusca. They all need attention for good management measures to be in place so that maize farmers can derive joy from their toil. $E$. saccharina was the most parasitized stem borer by parasitoids in the University farm and the Cafeteria over the minor season.

The results also showed that syzeuctus sp. was the commonest parasitoid attacking stem borers in the experimental farms. On the contrary, Mohyuddin and Greathead (1970) as well as Harris (1998) reported the Tachinid fly, Sturmiopsis parasitica to be the most important parasitoid in West and East Africa parasitizing number of stem borer species.

$S$. parasitica (Plate 4a) was collected from the larvae of E. saccharina, B. fusca, Sesamia spp., and E. saccharina. 
Table 2. Number of stem borer larvae and rate of parasitism at each age of the maize plant in the University farm in the minor season.

\begin{tabular}{ccccccccc}
\hline $\begin{array}{c}\text { Age of plant } \\
\text { (in weeks) }\end{array}$ & \multicolumn{2}{c}{ Sesamia spp. } & \multicolumn{2}{c}{ Eldana saccharina } & \multicolumn{2}{c}{ Busseola fusca } & \multicolumn{2}{c}{ Chiloale niellus } \\
\cline { 2 - 9 } & No & \% parasitism & No & \% parasitism & No & \% parasitism & No & \% parasitism \\
\hline 4 & 34 & 0.0 & 0 & - & 0 & - & 0 & - \\
5 & 80 & 0.0 & 0 & - & 3 & 0.0 & 0 & - \\
6 & 51 & 0.0 & 0 & - & 6 & 0.0 & 0 & - \\
7 & 46 & 0.0 & 3 & 0.0 & 11 & 0.0 & 0 & - \\
8 & 22 & 0.0 & 4 & 0.0 & 8 & 0.0 & 0 & - \\
9 & 9 & 0.0 & 3 & 0.0 & 2 & 0.0 & 0 & - \\
10 & 8 & 0.0 & 9 & 0.0 & 6 & 0.0 & 0 & - \\
11 & 3 & 0.0 & 13 & 0.0 & 5 & 0.0 & 0 & - \\
12 & 2 & 0.0 & 13 & 0.0 & 1 & 0.0 & 0 & - \\
13 & 7 & 0.0 & 17 & 5.88 & 3 & 0.0 & 1 & 0.0 \\
14 & 0 & - & 9 & 0.0 & 2 & 0.0 & 0 & - \\
15 & 0 & - & 4 & 25.0 & 0 & - & 2 & 0.0 \\
Total & 262 & 0.0 & 75 & 30.88 & 47 & 0.0 & 3 & 0.0 \\
\hline
\end{tabular}

Table 3. Parasitoid species and their hosts during the minor season of 1996 in experimental farms.

\begin{tabular}{cllllc}
\hline $\begin{array}{c}\text { Age of plants (in } \\
\text { weeks) }\end{array}$ & Site & Species & $\begin{array}{l}\text { Stem borer } \\
\text { host }\end{array}$ & $\begin{array}{l}\text { Host } \\
\text { stage }\end{array}$ & $\begin{array}{c}\text { Rate of parasitism per } \\
\text { sampling date \%) }\end{array}$ \\
\hline 3 & Cafeteria & Unidentified Chloropid & Sesamia spp. & L & 2.70 \\
9 & Cafeteria & Syzeuctus sp. & E. saccharina & L & 22.22 \\
10 & Cafeteria & Syzeuctussp & E. saccharina & L & 10.0 \\
11 & Farm & Stenobracon*sp & - & - & - \\
\hline
\end{tabular}

$\mathrm{L}=\mathrm{L}$ arva, ${ }^{*}$ Collected from borer tunnel.

Syzeuctus sp. (Plate $3 a$ ) was also collected from larval $E$. saccharina, and B. fusca; Enicospilus sp. (Plate 4b) from larval B. fusca; Pediobus furvus (Plate 4c) was collected from B. fusca pupae; unidentified Muscid (Plate 4d), unidentified Phorid and unidentified Diptera (Plate 4e) from $B$. fusca larvae; Dolichogenidea sp. (Plate 4f) and Aphanogmus fijiensis (Plate $4 \mathrm{~g}$ ) were collected from stem borer tunnels. These findings corroborate that of Harris (1998) which reported S. parasiticaa as an important larval parasitoid of gramineous stem borers in Africa. In Ethiopia the Braconid, Dolichogenidea fuscivora was found to be the major larval parasitoids of $B$. fusca with parasitism of $71 \%$ during the dry season and $18 \%$ in the wet season (CIMMYT, 2011). Pediobius furvus is a gregarious primary pupal parasitoid of $B$. fusca in maize and sorghum in Ethiopia. According to CIMMYT (2011) Stenobracon rufus is a solitary pupal parasitoid of $B$. fusca in Ethiopia with parasitization rate of $14 \%$. Studies by Tefera (2004) in Ghana reported that the exotic species Trichogramma have high fecundity and helped to control stem borers, including B. fusca. In Southern Benin, Telenomus busseola (Ghana) (Hymenoptera: Sclionidae) and Telenomus isis (Polaszek) (Hymenoptera: Sclionidae) are the most important natural control factors of stem borers, including $B$. fuscaon maize (Tefera, 2004).
Mailafiya et al. (2011) reported that in maize, plant infestation, stem borer density, larval parasitism and total parasitism were significantly different amongst localities. Similarly, Chinwada and Overholt (2001) observed many natural enemies associated with maize stem borers on the Highveld region and outside. These suggest the distribution and abundance of the parasitoids according to ecological zones and regions.

During the surveys, Syzeuctus sp. was collected from 5 regions (Ashanti, Greater Accra, Eastern, Western and Central Regions); S. parasitica was collected from 3 regions (Western, Eastern and Ashanti regions), Dolichogenidea sp. from two regions (Western and Central regions); $A$. fijiensis from two regions (Eastern and Western Regions); Pediobus furvus, a pupal parasitoid from two regions (Ashanti and BrongAhafo regions) and each of the three unidentified parasitoid species was collected from one region each (Muscidae from Western Region, unidentified Diptera from Greater Accra Region and the Phoridae from Ashanti Region) (Table 4). Throughout the survey, no parasitoid was collected from Volta Region. However, parasitoid pupal cases were removed from dead larvae indicating parasitism in some fields in the Region.

Taking the data in Table 4 into consideration, Ashanti 


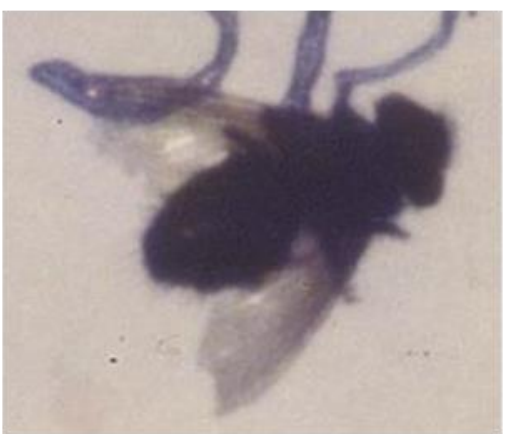

(a)

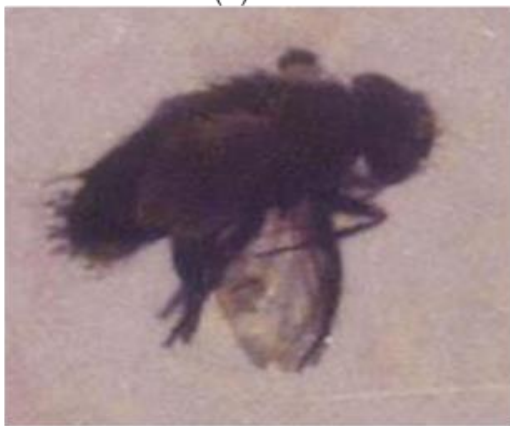

(d)

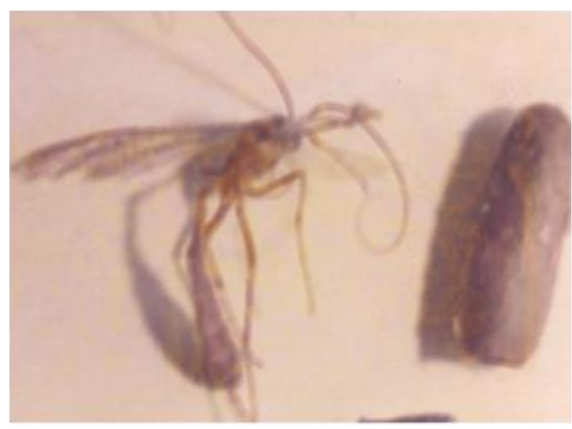

(b)

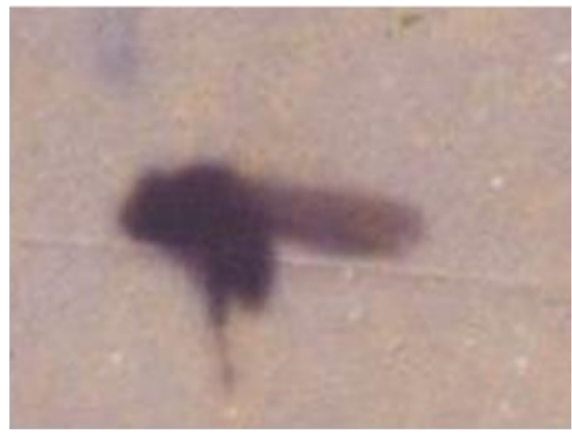

(e)

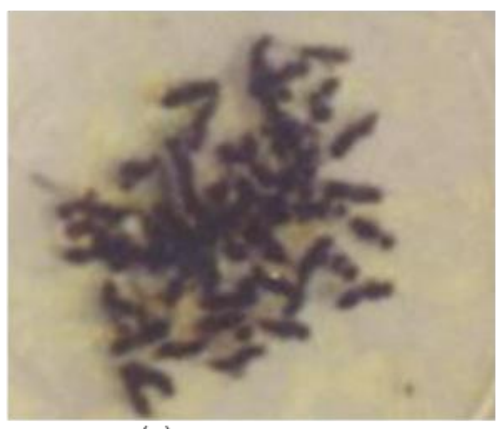

(c)

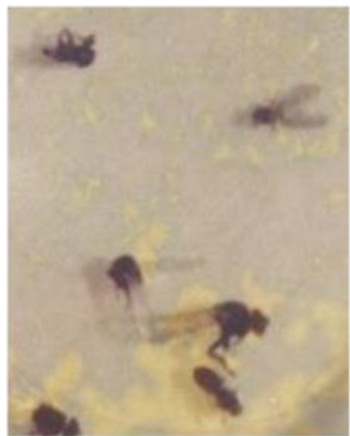

(f)

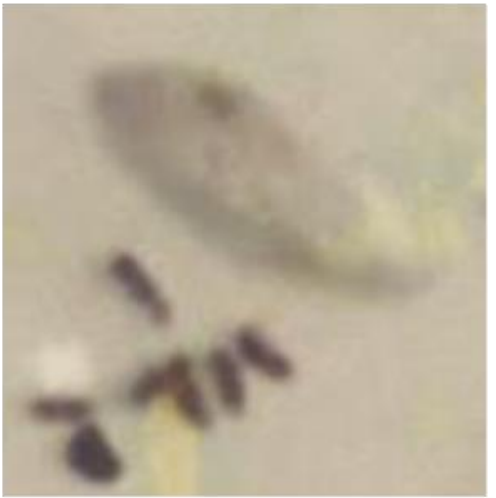

(g)

Plate 4. Parasitoids collected during the survey:(a) Sturmiopsis parasitica (X5); (b) Enicospilus (Ophion) sp. and pupa case (X4); (c) Pediobus furvus (mass) X10; (d) Unidentified Muscid (X5); (e) An unidentified Diptera (X5); (f) Dolichogenidea sp (X10); (g) A.fijiensis and pupa case (cocoon) X10.

and Western regions had the highest diversity of parasitoids species (5 different types each) followed by Eastern and Central regions (4 different types each), Greater Accra Region (2 different types) and BrongAhafo Region (1 type). However, Eastern Region was the Region with the most abundant parasitoids (14 parasitoids) followed by Ashanti Region (8 parasitoids), Western Region (5 parasitoids), Central Region (4 parasitoids), Greater Accra (2 parasitoids) and Brong Ahafo Region (1 parasitoid) as in Table 4 . The differences in regional diversity and abundance of the parasitoids may be attributed to different geographical and agro-ecological conditions in the various regions. On large scale, Ashanti, Western and Eastern regions of Ghana are dominated by forest conditions, suggesting that such agro-ecological zone might have encouraged the abundance and diversity of the parasitoids in the three regions. This may be useful to maize farmers in the three regions because it may cause increased yield of maize and thus boosting the income of the farmers.

Syzeuctus sp. was the parasitoid species with the highest number of regional distribution (4 regions), followed by $S$. parasitica and Enicospilus sp. (3 regions each), Dolichogenidea sp. and Pediobusfurvus (2 regions 
Table 4. Regional distribution of larval and pupal parasitoids.

\begin{tabular}{|c|c|c|c|c|c|c|c|}
\hline \multirow{2}{*}{$\begin{array}{l}\text { Season } \\
\text { Major }\end{array}$} & \multirow[t]{2}{*}{ Parasitoid species } & \multicolumn{6}{|c|}{ Number of fields per region } \\
\hline & & BA & Ashanti & GA & Western & Central & Eastern \\
\hline & Sturmiopsisparasitica & - & 1 & - & - & - & - \\
\hline & Syzeuctus sp. & - & - & 1 & - & - & - \\
\hline & Pediobusfurvus & 1 & - & - & - & - & - \\
\hline & Unidentified Muscid & - & - & - & 1 & - & - \\
\hline & Unidentified Diptera & - & - & 1 & - & - & - \\
\hline \multirow[t]{7}{*}{ Minor } & Sturmiopsisparasitica & - & 1 & - & - & 1 & 7 \\
\hline & Syzeuctus sp. & - & 3 & - & 1 & 1 & 4 \\
\hline & Dolichogenidia sp. & - & - & - & 1 & 2 & - \\
\hline & Aphanogmusfijiensis & - & -- & - & 1 & - & 1 \\
\hline & Enicospilus sp. & - & 1 & - & 1 & - & 1 \\
\hline & Pediobusfurvus & - & 1 & - & - & - & - \\
\hline & Unidentified Phorid & - & 1 & - & - & - & - \\
\hline
\end{tabular}

$\mathrm{BA}=$ BrongAhafo Region; GA = Greater Accra Region.

Table 5. Ecological distribution of larval parasitoids of lepidopterous maize stem borers in Ghana - 1996.

\begin{tabular}{|c|c|c|c|}
\hline \multirow{2}{*}{ Season } & \multirow{2}{*}{ Parasitoid species } & \multicolumn{2}{|c|}{ Percentage number in each ecological zone } \\
\hline & & Transition forest & Coastal Savannah \\
\hline \multirow[t]{5}{*}{ Major } & Sturmiopsisparasitica & 20.0 & 0.0 \\
\hline & Syzeuctus sp. & 40.0 & 0.0 \\
\hline & Unidentified muscid & 0.0 & 20.0 \\
\hline & Unidentified dipteral & 0.0 & 20.0 \\
\hline & Total & 60 & 40 \\
\hline \multirow[t]{8}{*}{ Minor } & & Transition forest & Forest \\
\hline & Sturmiopsisparasitica & 0.0 & 28.57 \\
\hline & Syzeuctus sp. & 2.38 & 47.62 \\
\hline & Dolichogenidia sp. & 4.76 & 2.38 \\
\hline & Aphanogmusfijiensis & 2.38 & 2.38 \\
\hline & Enicospilus sp. & 2.38 & 4.76 \\
\hline & Unidentified phorid & 2.38 & 0.0 \\
\hline & & 14.28 & 85.71 \\
\hline
\end{tabular}

each), A. fijiensis, unidentified Muscid, Diptera and Phorid (1 region each). In terms of number of fields also, Syzeuctus sp. was the parasitoid with the widest distribution (Table 4). This is surprising because thorough literature search on parasitoids of lepidopterous maize stem borers shows high level of paucity of information on Syzeuctus sp. However, findings from this study suggest that Syzeuctus sp. is a prominent stem borer control agent in Ghana.

During the major season survey, only five parasitoids emerged from stem borers. These five parasitoids were from two ecological zones, namely, transition forest and coastal savannah (Table 5). Sixty per cent of the parasitoids emerged from borers in the transition forest zones. Forty percent of this was Syzeuctus sp. whilst 20 was $S$. parasitica. None of the unidentified species was collected from the transition forest but rather from the Coastal savannah. Twenty percent of the parasitoids from the Coastal savannah were unidentified muscids and another $20 \%$ were unidentified diptera.

During the minor season, 42 parasitoids emerged from stem borers. Out of this $85.71 \%$ were obtained from the forest zone. Out of the $85.57 \%, 47.62 \%$ was Syzeuctus sp., $28.57 \%$ was Sturmiopsis parasitica and less that $5 \%$ of each of the others emerged from the stem borers in the forest zone. The remaining $14.28 \%$ of the parasitoids 
emerged from stem borers in the transition forest. It is generally clear that very low percentage of parasitoids was recorded for borers in the transition forest (Table 5).

The relatively high number of Syzeuctus sp. and $S$. parasitica in the forest zones could be as a result of high relative humidity $(\mathrm{RH})$ (Sampson and Kumar, 1986) and shade in the forest zones. This could explain why in the heavy rains of the major season where humidity was high, the parasitoids were found in the savannah areas compared to the minor season when $\mathrm{RH}$ was relatively low.

Human activities in the various ecological zones could lead to destruction of the ecosystem that would attract or affect the parasitoids. Similarly, bush fires can kill the parasitoids which are less effective fliers. So, the very poor performance of the parasitoids in other ecological zones (coastal savannah and grassland savannah) may also be attributed to bush fires and constant human activities in these ecological zones.

\section{Conclusions and recommendations}

The stem borer pests infesting maize plants in the experimental farms are Sesamia spp., E. saccharina, $B$. fusca and C. aleniellus. Also, S. calamistis proved to be the most significant borer infesting maize plants around the experimental areas. The findings show that in the experimental areas in Cape Coast, high numbers of stem borers could be obtained in the minor season compared to the major season. Low infestations can also be obtained when the maize plants are matured above 11 weeks old.

The present study has established that there are parasitoids in the experimental areas controlling stem borer species. Meanwhile, low rates of parasitism were recorded in the experimental farms suggesting that more thorough research needs to be conducted in the area to ascertain the true nature of stem borer parasitism in the area. Notwithstanding, E. saccharina appear to be the most parasitized stem borer in the University farm and the Cafeteria over the minor season. This suggests that if conditions are created in the research area to protect parasitoids, stem borers may be controlled, especially $E$. saccharina.

It can also be concluded that in southern Ghana, Ashanti and Western regions have higher diversity of the parasitoids whereas Eastern Region harbours them most. Therefore, efforts should be made to study the factors in the three regions that favour the parasitoids in order to harness their multiplication to control the borer complex. Syzeuctus sp. with the highest regional distribution (4 regions), suggests that it is of prominence and needs to be exploited for controlling maize stem borers in Ghana. It is further evident that forest zones are the two important agro-ecological zones having the highest number of parasitoids.
Since the effects of stem borers on the maize plants can be felt most when plants are less than 11 weeks old, agricultural officers need to educate farmers to initiate control measures in the earlier weeks of the plants. Once there are parasitoids in the wild controlling the stem borers, agricultural officers should team up with research scientists to know more about these parasitoids and appropriately help farmers. In the meantime, farmers should desist from indiscriminate synthetic insecticide control measures that can exterminate the parasitoids. Going forward, research scientists should develop the mechanism of mass rearing of $S$. parasitica, Syzeuctus sp., Enicospilus sp., P.furvus, Dolichogenidea sp., A. fijiensisand and other parasitoids that coexist with the stem borer complex in the research area and use the best strategies to release them in their populations to control stem borers.

Agricultural officers should study the factors responsible for relative abundance and diversity of borer parasitoids in Ashanti, Western and Eastern regions as well as in the forest zones so that the appropriate steps can be taken to educate farmers in the areas to protect the parasitoids for effective maize stem borer control.

\section{CONFLICT OF INTEREST}

The authors declare that they have no conflict of interest.

\section{REFERENCES}

Adu, G. B., Abdulai, M. S., Alidu, H., Nutsugah, S. K., Buah, S. S., Kombiok, J. M. Obeng-Antwi, K., Abudulai1, M., \& Etwire, P. M. (2014). Recommended Production Practices for Maize in Ghana. CSIR/AGRA. 18p.

AQUASTAT (2005). Ghana: Geography, Climate and Population. Irrigation in Africa in figures - AQUASTAT Survey 2005. Rome: FAO. Retrieved from www.GH-CP_eng.pdf on 21st January, 2018.

Bosque-Pérez, N. A., \& Mareck, J. H. (1991). Effect of the stem borer Eldanasaccharina (Lepidoptera: Pyralidae) on the yield of maize. Bulletin of Entomological Research, 81, 243-247

Bosque-Pérez, N. A., \& Schulthess, F. (1998). Maize: West and Central Africa. In: Polaszek (ed.). African Cereal Stem Borers: Economiclmportance, Taxonomy, Natural Enemies and Control. CTA/CABI International, Wallingford.

Chabi-Olaye, A., Nolte, C., Schulthess, F., \& Borgemeister, C. (2005). Effects of grain legumes and cover crops on maize yield and plant damage by Busseolafusca(Fuller) (Lepidoptera: Noctuidae) in the humid forest of southern Cameroon. Agr. Ecosyst. Environ., 108, 17-28.

Chabi-Olaye, A.; Schulthess, F., \& Borgemeister, C. (2008). Effects of nitrogen and potassium combinations on yields and infestations of maize by Busseolafusca (Fuller) (Lepidoptera: Noctuidae) in the humid forest of Cameroon. J. Econ. Entomol., 101, 90-98.

Chinwada, P. and Overholt, W.A. (2001). Natural enemies of maize stem borers on the highveld of Zimbabwe. African Entomology, 9, 67-75. 
CIMMYT (International Maize and Wheat Improvement Center) (2011). Meeting the challenges of global climate changes and food security through innovative Maize research, proceeding of 3rd National Maize workshop of Ethiopia, Addis Ababa, Ethiopia: CIMMYT. Pp. 185-300.

Crop Research Institute (CRI) (1996). Obatanpa-A new maize variety with high quality protein for farmers. Factsheet. Kumasi: Crop Research Institute, Training and communication Unit.

Deeming, J. C. (1972). A review of the taxonomy of African shoot flies of sorghum. In M. G. Jowanti and W. R. Young (eds.), Control of sorghum shoot fly. New Delhi, India: Oxford and IBH Publishing Co.

Harris, K. M. (1990). Bioecology of Chilospecies. Insect Science and its Application, 11, 467-477.

Harris, K. M. (1998). Diptera. In A. Polaszek (ed.), African cereal stem borers: economic importance, taxonomy, natural enemies and control. Wallingford, United Kingdom: CAB International.

Harris, C. W., \& Nwanze, K. E. (1992). Busseola fusca (Fuller), the African maize stalk borer: A handbook of information. In Information Bulletin No. 33; ICRISAT, CAB International: Oxon, UK, p. 85.

Ingram, W. R. (1958). The Lepidopterous stalk borers associated with Gramineae in Uganda. Bulletin of Entomological Research, 49, 367-383.

Kaufman, T. (1983). Behavioural Biology, Feeding Habits and Ecology of three species of maize stem borers: Eldanasaccharina (Lepidoptera: Pyralidae), Sesamiacalamistis and Bsseolafusca (Noctuidae) in Ibadan, West Africa. Journal of the Georgia Entomological Society, 18, 259-272.

Kfir, R., Overholt, W. A., \& Khan, Z. R. (2002). Polaszek, A. Biology and management of economically important lepidopteran cereal stem borers in Africa. Annu. Rev. Entomol., 2(47), 701-731.

Kumar, R., \& Sampson, M. (1982). Mini review, Review of Stem Borer Research in Ghana. Insect Science and its Application, 13(2/3), 85-88.

Kwapong, P. (1990). The Bionomics of Eldanasaccharina and the effects of inter-cropping and time of planting on the stem borer complex on maize in the Central Region of Ghana. A thesis submitted to the Department of Zoology for the degree of Master of Science, University of Cape Coast, p. 84.

Maafo, J. K. (1975). Laboratory mass rearing of exotic Tetrastichus spp. for the control of maize and sugarcane stem borers in Ghana. Ghana Journal of Agricultural Science, 8, 8993.

Maes, K. V. N. (1998). Pyraloidea: Crambidae, Pyralidae. In: A. Polaszek (editor). AfricanCereal Stem Borers: Economic Importance, Taxonomy, Natural Enemies and Control. CTA/CABI International. Pp. 87-98.

Mailafiya, D. M., Le Rum, B. P., Kairu, E. W., Stéphane Dupa, S., \& Calatayud, P. (2011). Parasitism of lepidopterous stem borers in cultivated and natural habitats. Journal of Insect Science, 11, 1-19. Retrieved from www.insectscience.org on 14th January, 2018.

Ministry of Food and Agriculture (MOFA) (2011). Agriculture in Ghana: Facts and figures, 2010. Accra, Ghana: Statistics, Research and Information Directorate (SRID) of MOFA.
Mohyuddin, A. I., \& Greathead, D. J. (1970). An annotated list of the parasites of graminaceous stem borers in East Africa, with a discussion of their potential in biologicalcontrol. Entomophaga, 15, 241-274.

Ndemah, R., Schulthess, F., Poehling, M, Borgemeister, C., \& Goergen, G. (2001). Natural enemies of lepidopterous borers on maize and elephant grass. Bulletin of Entomological Research, 91, 205-212.

Ntambo, M. S., Manyangarirwa, W., Tuarira, M., \& Onesime M. K. (2015). Effect of LepidopterousStemborers, Busseolafusca(Fuller) and Chilopartellus (Swinhoe) on Maize (Zea mays L) Yield: A Review. International Journal of Innovative Research and Development, 4(10), 181-188.

Paul-André, C., Le Ru, B. P., van den Berg, J., \& Schulthess, F. (2014). Ecology of the African Maize Stalk Borer, Busseola fusca (Lepidoptera: Noctuidae) with Special Reference to Insect-Plant Interactions. Insects, 5, 539-563.

Polaszek, A. (1994). Cereal stem borers in Africa: Taxonomy, natural enemies and control. Training Course Handbook. Nairobi, Kenya; 8-19th August, 1994.

Polaszek, A., \& Lassale, J. (1995). The hyperparasitoids (Hymenoptera: Ceraphronidae) of cereal stem borers (Lepidoptera: Noctuidae, Pyralidae) in Africa. African Entomology, 3, 131-146.

Risbec, J. (1960). Les parasite des insects et a Madagasca. AgronomieTropicale, 15, 624-656.

Sampson, M. A., \& Kumar, R. (1985). Life history, development and behaviour of Eldanasaccharina Walker on sugarcane in Southern Ghana. Insect Science and its Application, 16(2), 135-149.

Sampson, M. A., \& Kumar, R. (1986). Parasitism of Descampsinasesamiae (mensal) on Sesamia species in sugarcane in Southern Ghana. Insect Science and its Application, 7(4), 543-546.

Shanower, T. G., Schulthess, F., \& Gounou, S. (1991). Distribution and abundance of some stem and cob borers in Benin. Plant Health Management Research Monograph 1. Ibadan, Nigeria: International Institute of Tropical Agriculture.

Smith, J. W. Jr., Wiedenmann, R. N., \& Overholt, W. A. (1993). Parasites of lepidopteran stem borers of tropical gramineous plants. Nairobi, Kenya: ICIPE Science Press.

Tefera, T. (2004). Lepidopterpous stem borers of sorghum and their natural enemies in Eastern Ethiopia. Trop. Sci, 44, 128130.

Tounou, A. K., Agboka, K., Agbodzavu, K. M., \& Wegbe, K. (2013). Maize stem borers distribution, their natural enemies and farmers' perception on climate change and stem borers in southern Togo. Journal of Applied Biosciences, 64, 47734786 . 